\title{
Effect of Long-Term Conservation Agriculture on Soil Organic Carbon and Dehydrogenase Activity under Maize-Based Cropping Systems
}

\author{
Amresh Chaudhary, Mahesh C. Meena*, Chiter M. Parihar and Abir Dey
}

ICAR-Indian Agricultural Research Institute (ICAR-IARI), New Delhi, 110012, India

*Corresponding author

\begin{tabular}{|c|c|}
\hline & A B S T R A C T \\
\hline Keywords & \multirow{6}{*}{$\begin{array}{l}\text { A long-term field experiment on conservation agriculture (CA) is continuing since } 2008 \text { at } \\
\text { the research farm of the ICAR-Indian Institute of Maize Research (IIMR), New Delhito } \\
\text { evaluate the impact of twelve combinations of tillage practices (03) and irrigated intensive } \\
\text { maize-based systems (04) on Walkley and Black C (WBC) and dehydrogenase activity of } \\
\text { a sandy loam soil in north-western Indo-Gangetic plains of India. The CA-based tillage } \\
\text { practices consist of zero-till(ZT), permanently raised beds (PB) and conventional tillage } \\
\text { (CT) in main-plots and four intensive irrigated maize-based crop rotations (MWMb: } \\
\text { maize-wheat-mungbean, MCS: maize-chickpea-Sesbania, MMuMb maize-mustard- } \\
\text { mungbean, MMS: maize-maize-Sesbania) in sub-plots. Results revealed that across the } \\
\text { soil depths, WBC content of different tillage practices and diversified cropping systems } \\
\text { varied from } 0.55 \text { to } 0.40 \% \text {. The CA-based practices resulted in higher WBC over CT, and } \\
\text { the value decreased with soil depth. The DHA registered } 49.2 \text { and } 50.1 \% \text { higher in } 0-5 \text { and } \\
5-15 \text { cm soil depth under PB over CT, respectively which showed improvement in soil } \\
\text { health and SOC due to crop diversification. Thus, our long-term study suggests that PB } \\
\text { and ZT with diversified maize-based systems i.e. MCS and MWMb can be advocated for } \\
\text { restoration and improvement in soil health of light textured soils of north-western India. }\end{array}$} \\
\hline & \\
\hline $\begin{array}{l}\text { Conservation } \\
\text { agriculture, Zero- } \\
\text { tillage, Soil organic } \\
\text { carbon, }\end{array}$ & \\
\hline $\begin{array}{l}\text { Dehydrogenase } \\
\text { activity, Maize- } \\
\text { based cropping } \\
\text { systems. }\end{array}$ & \\
\hline Article Info & \\
\hline $\begin{array}{l}\text { Accepted: } \\
\text { 07 September } 2017 \\
\text { Available Online: } \\
\text { 10 October } 2017\end{array}$ & \\
\hline
\end{tabular}

\section{Introduction}

Soil organic carbon (SOC) is the epicenter of soil physical, chemical and biological health (Chen et al., 2017; He et al., 2015). Indiscriminate use of fertilizers in post green revolution era (for the past four decades) discouraged application of organic matter in soil which ultimately reduced SOC to a very low level $(<0.5 \%)$ (Velayutham et al., 2000). Tillage is manipulation of soil for providing better condition for plant growth but also increases the rate of SOC mineralization resulting in SOC loss. In India, about $500 \mathrm{Mt}$ of crop residue (CR) is generated through agricultural production system annually, and more than one-fifth of those are disposed of by burningto clear fields after harvest (Aulakh et al., 2012). Crop-residue burning is a major cause of environmental pollution especially in the north western part of Indo-gangetic plains (NW-IGP) (Punia et al., 2008) resulting in environmental pollution, generation of greenhouse gases and loss of soil nutrients. Therefore, proper management of crop residues is crucial for sustainable agriculture (Meena et al., 2017). Conservation agriculture is a crop management based practices on notillage, residue retention and crop diversification and has potential to increase 
the soil organic matter content through efficient management of crop residue.

Maize-based diversified cropping system has been found as a better alternative to ricewheat cropping system due to its low irrigation water requirement, higher productivity and better adaptability to harsh environment due to its $\mathrm{C}_{4}$ nature and increasing demand for maize in livestock and processing industries (Parihar et al., 2016). Diversified maize-based rotation promoted accumulation of SOC in Inceptisols (Nath et al., 2017). No-till maize-based crop rotation reported a reduction in greenhouse gas emission in the form of nitrous oxide along with improvement in soil carbon status (Lehman et al., 2017). Conservation agriculture improves soil biological properties, microscopic bio-diversity and enzyme activities (Dai et al., 2017). However, detection of change in SOC content in different soil layers due to alteration of tillage practices from conventional to conservation (no-tillage) is difficult over a short period of time. Information regarding long-term effects of different tillage practices and maize-based cropping systems on Walkley-Black carbon (WBC) and its impact on biological activities in the IGP is scarce. Therefore, there is need for extensive study of long-term effect of CA on SOC and soil health. In the current study we hypothesized that residue retention on soil surface during different cropping seasons under similar type of agronomic management practices would result in difference in SOC content and dehydrogenase activity. The aim of this study was to evaluate the best cropping system in terms of SOC status, and dehydrogenase activity (DHA) activity as affected by tillage and residue retention.

\section{Materials and Methods}

\section{Experimental site and treatment details}

A long-term field experiment on conservation agriculture (CA) with different cropping systems has been initiated in the year 2008 at the research farm of the ICAR-Indian Institute of Maize Research (IIMR), New Delhi, and is continued till date. The site is situated at $28^{\circ} 4^{\prime}$ $\mathrm{N}$ latitude, $77^{\circ} 12^{\prime} \mathrm{E}$ longitude and 228.6 meters above mean sea level. The experimental soil was taxonomically characterized as Typic Haplustept, neutral and non-saline in nature. Important soil properties are given in Table 1. Delhi represents semiarid sub-tropical environment with cold winter and hot summer. The mean annual precipitation is about $650 \mathrm{~mm}$, which is mostly through by $\mathrm{N}-\mathrm{W}$ monsoon contributing $80 \%$ of total rainfall in this reason. The mean daily evapotranspiration was $10.9 \mathrm{~mm}$ in the month of June and minimum $(1.5 \mathrm{~mm})$ in January. The annual pan evaporation was approx. $850 \mathrm{~mm}$. The maximum value of mean relative humidity approaches during the south-west monsoon period and the minimum in the hot summer months.

The experiment was laid-out in split-plot design with three tillage practices of which two are CA-based practices like permanent bed (PB) and zero tillage (ZT) with $30 \%$ crop residues retained on the soil surface in each year, and a conventional tillage (CT) in mainplots and four sub-plots consisting of cropping systems i.e. maize-wheat-mungbean (MWMb), maize-chickpea-Sesbania (MCS), maize-mustard-mungbean (MMuMb) and maize-maize-Sesbania (MMS), withthree replications (Table 2).

\section{Soil sample collection and analysis}

Depth-wise soil samples (0-5, 5-15 and 15-30 $\mathrm{cm})$ were collected after harvesting of kharif crop in October 2015. Samples were air dried, ground with wooden pestle and mortar and passed through $0.2 \mathrm{~mm}$ sieve to determine the SOC content as procedure outlined by Walkley and Black (1934) and reported as 
WBC. Samples were also collected after harvesting of crops in each season i.e. kharif, rabi and summer seasons from two soil depths i.e. $0-5,5-15 \mathrm{~cm}$. Immediately, the fresh samples were used for determination of dehydrogenase activity according to Casida et al. (1984). The 2, 3, 5-triphenytetrazolium chloride was added to field moist soil along with glucose solution. After 24 hours incubation at $37^{\circ} \mathrm{C}$, formed triphenyformazon was extracted with methanol and measured spectrophotometrically at $485 \mathrm{~nm}$.

\section{Statistical analysis}

The data recorded for different parameters were analyzed with the help of analysis of variance (ANOVA) technique (Gomez and Gomez 1984) for split-plot design using SAS 9.1 software (SAS Institute, Cary, NC). The least significant difference (LSD) test was used to decipher the effect of treatments at $5 \%$ level of significance $(\mathrm{P}=0.05)$.

\section{Results and Discussion}

\section{Walkley-Black C}

Walkley-Black C (WBC) content under longterm tillage practices was highest under ZT with average value $0.46 \%$ across the soil depths (Table 3). The WBC content under PB was statistically similar to ZT at different soil depths, whereas CT contained lowest WBC. The WBC content under PB and CT averaged across the soil depth was $0.44 \%$ and $0.39 \%$, respectively. Compared with CT, WBC content of $0-5 \mathrm{~cm}$ soil layer was higher under PB and ZT by 21.3 and $19.7 \%$, respectively. In $5-15 \mathrm{~cm}$ depth, PB and ZT had similar and significantly higher WBC $(0.47 \%)$ compare to CT $(0.40 \%)$. Differences between tillage practices were not significant at $15-30 \mathrm{~cm}$ depth. The WBC content was reported in different cropping systems, which followed the trend as MCS $>M W M b>M M S>M M u M b$ across the soil depths. The interaction between tillage and cropping systems were significant for $0-5 \mathrm{~cm}$ and $15-30 \mathrm{~cm}$ depth, and shown the advantage of adoption of CA treatments (PB and ZT) equally in MCS and MWMb systems (Fig. 1).

\section{Dehydrogenase activity}

Dehydrogenase activity (DHA) was found significantly higher in $\mathrm{PB}$ and ZT over CT in all soil depth across the seasons. Under PB, DHA was 49.2 and $50.1 \%$ higher compared to CT in $0-5 \mathrm{~cm}$ and $5-15 \mathrm{~cm}$ soil depths, respectively, during the rabi season (Table 4). Soil DHA was lower in lower depths, irrespective of treatments. Across the seasons, DHA was highest in kharif followed by summer and rabi with a range of 31.8-63.8, 31.0-61.5 and 29.3-57.0 $\mu \mathrm{g} \mathrm{TPFg}^{-1} 24 \mathrm{~h}^{-1}$, respectively. In respect to cropping systems, DHA values decreased in the order: MCS $>M W M b>M M S>M M u M b$ irrespective of soil depths and seasons. Dehydrogenase activity was 39.6 and $24.5 \%$ higher in MCS over MMuMb in $0-5 \mathrm{~cm}$ and $5-15 \mathrm{~cm}$ soil depths, respectively in the kharif season. Similar trend was recorded for rabi and summer seasons. Interaction of tillage practices and cropping systems was not significant for either soil depths or seasons.

In the present investigation, long-term effect of CA practices viz. $\mathrm{PB}, \mathrm{ZT}$ vis-à-vis $\mathrm{CT}$ was evaluated on WBC and DHA activity under different maize-based cropping systems.WBC contents under $\mathrm{PB}$ and $\mathrm{ZT}$ were greater than CT in the present case (Table 3). These results are expected in the light of $\mathrm{C}$ input through retention of crop residues and minimum soil disturbance. The CA has high potential for $\mathrm{C}$ sequestration and conversion to no-till farming helps sequestering $\mathrm{C}$ in soil (Dey et al., 2016). A few reports contradicted the claims made regarding improvement in SOC content owing to adoption of CA (Yang and Wander 1999; Halvorson et al., 2002; Thomas et al., 2007). The present study 
however did not substantiate such reports. Earlier studies further suggest only small changes in WBC content of soil when measured over short-term because of large quantity of background organic matter present in soil (Lal, 2015). Contrarily there has been significant change in $\mathrm{WBC}$ content in the present study. Such changes in WBC may be attributed due to adoption of $\mathrm{CA}$ which involves substantial amount of residue retention (30\% of the above ground residues of kharif and rabi crops) vis-à-vis CT with residue removal. Averaged across soil depths, MCS and MWMb accumulated relatively higher WBC compared with $\mathrm{MMuMb}$ and MMS which indicate that inclusion of chickpea or wheat as rabi crop appeared to be a superior option compared to mustard or winter maize as far as SOC accumulation is concerned. The finding of present study is in line with the published literature on depthwise distribution of SOC in crop lands (Mandal et al., 2013; Singh et al., 2015). This study corroborated the findings of Bhattacharyya et al., (2012) suggesting thereby the advantage of minimum soil disturbance (PB and $\mathrm{ZT}$ ) and crop wise residue retention on soil surface.

Dehydrogenase activity (DHA) measured during different seasons was invariable higher under $\mathrm{CA}$ (PB and ZT) compared with $\mathrm{CT}$ irrespective of soil depth (Table 4). An improvement in DHA content under CA practices is very much explainable in the light of possible flux in the microbial activity owing to less soil disturbance and retention of crop residues on the soil surface (Liu et al., 2014).

Table.1 Some important initial physicochemical properties of the experimental soil

\begin{tabular}{lll}
\hline Parameter & Values & Reference \\
\hline Mechanical composition & & Bouyoucos (1962) \\
Sand (\%) & 64.1 & \\
Silt (\%) & 12.6 & \\
Clay (\%) & 23.4 & \\
Texture & Sandy loam & \\
pH & 7.8 & Jackson (1973) \\
$\mathrm{EC}\left(\mathrm{dSm}^{-1}\right)$ & 0.32 & Jackson (1973) \\
Bulk density $\left(\mathrm{Mg} \mathrm{m}^{-3}\right)$ & 1.58 & Veihmeyer and Hendrickson (1948) \\
$\mathrm{KMnO}_{4}{\mathrm{Oxidizable} \mathrm{N}\left(\mathrm{kg} \mathrm{ha}^{-1}\right)}_{0.5 \mathrm{M} \mathrm{NaHCO}_{3} \text {-extractable P }\left(\mathrm{kg} \mathrm{ha}^{-1}\right)}^{158}$ & Subbiah and Asija (1956) \\
Neutral $1 \mathrm{~N} \mathrm{NH}_{4} \mathrm{OAc}-$ extractable K $\left(\mathrm{kg} \mathrm{ha}^{-1}\right)$ & 11.6 & Olsen et al., (1954) \\
\hline
\end{tabular}

Table.2 Treatments details of long-term experiment

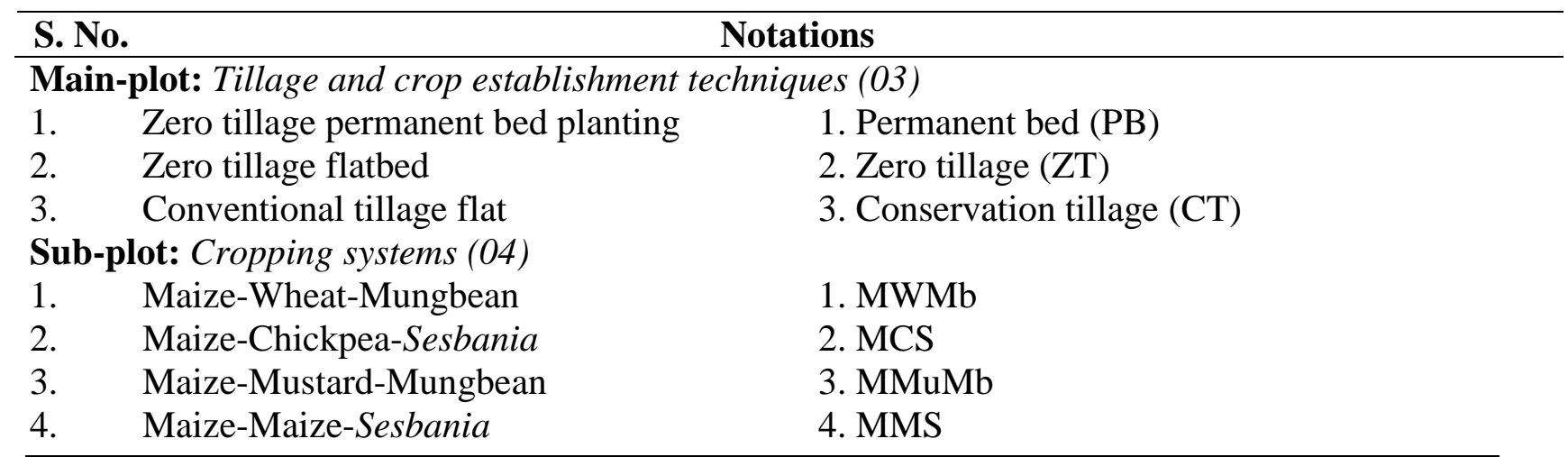


Table.3 Long-term effect of different tillage and cropping systems on depth-wise distribution of Walkley- Black C (WBC) after harvest of rabi crops

\begin{tabular}{lcccc}
\hline Treatment & \multicolumn{3}{c}{ WBC $(\%)$} \\
\cline { 2 - 4 } & $0-5 \mathrm{~cm}$ & $5-15 \mathrm{~cm}$ & $15-30 \mathrm{~cm}$ & Mean \\
\hline Tillage practices & & & 0.322 & 0.439 \\
Permanent bed & 0.552 & 0.443 & 0.351 & 0.455 \\
Zero tillage & 0.542 & 0.472 & 0.326 & 0.393 \\
Conventional tillage & 0.455 & 0.396 & $\mathrm{NS}$ \\
LSD $(p<0.05)$ & 0.038 & 0.049 & 0.363 & 0.458 \\
Cropping systems & & & 0.394 & 0.479 \\
MWMb & 0.566 & 0.444 & 0.363 \\
MCS & 0.565 & 0.479 & 0.315 & 0.415 \\
MMuMb & 0.461 & 0.370 & 0.333 & \\
MMS & 0.475 & 0.455 & 0.035 & \\
Mean & 0.517 & 0.437 & 0.060 & \\
LSD $(p<0.05)$ & 0.042 & $\mathrm{NS}$ & & \\
Interaction (LSD, $p<0.05)$ & 0.074 & &
\end{tabular}

Table.4 Season-wise changes in dehydrogenase activity ( $\mu \mathrm{g} \mathrm{TPF} \mathrm{g}^{-1} 24 \mathrm{~h}^{-1}$ ) under different treatment options

\begin{tabular}{|c|c|c|c|c|c|c|c|c|c|}
\hline \multirow{2}{*}{ Treatment } & \multicolumn{3}{|c|}{ Kharif } & \multicolumn{3}{|c|}{ Rabi } & \multicolumn{3}{|c|}{ Summer } \\
\hline & $0-5 \mathrm{~cm}$ & $5-15 \mathrm{~cm}$ & Mean & $0-5 \mathrm{~cm}$ & $5-15 \mathrm{~cm}$ & Mean & $0-5 \mathrm{~cm}$ & $5-15 \mathrm{~cm}$ & Mean \\
\hline \multicolumn{10}{|l|}{ Tillage practices } \\
\hline Permanent bed & 63.8 & 48.7 & 56.3 & 57.0 & 44.0 & 50.5 & 61.5 & 47.3 & 54.4 \\
\hline Conventional tillage & 42.2 & 31.8 & 37.0 & 38.2 & 29.3 & 33.8 & 40.7 & 31.0 & 35.9 \\
\hline $\operatorname{LSD}(p<0.05)$ & 8.2 & 5.5 & & 6.5 & 4.2 & & 6.5 & 4.2 & \\
\hline \multicolumn{10}{|l|}{ Cropping system } \\
\hline MCS & 65.9 & 48.2 & 57.1 & 57.3 & 42.9 & 50.1 & 62.8 & 46.8 & 54.8 \\
\hline $\mathrm{MMuMb}$ & 47.2 & 38.7 & 43.0 & 43.5 & 36.0 & 39.8 & 45.9 & 37.9 & 41.9 \\
\hline MMS & 51.9 & 40.6 & 46.3 & 46.7 & 37.1 & 41.9 & 49.9 & 39.5 & 44.7 \\
\hline Mean & 55.1 & 42.4 & 48.8 & 49.3 & 38.6 & 44.0 & 53.0 & 41.3 & 47.1 \\
\hline $\operatorname{LSD}(p<0.05)$ & 6.5 & 5.2 & & 5.9 & 3.4 & & 5.9 & 3.4 & \\
\hline Interaction $(\mathrm{LSD}, p<0.05)$ & NS & NS & & NS & NS & & NS & NS & \\
\hline
\end{tabular}


Fig.1 Interaction effect of long-term tillage practices and cropping systems on Walkley- Black C in different soil depths [Error bar shows LSD $(\mathrm{p}<0.05)]$

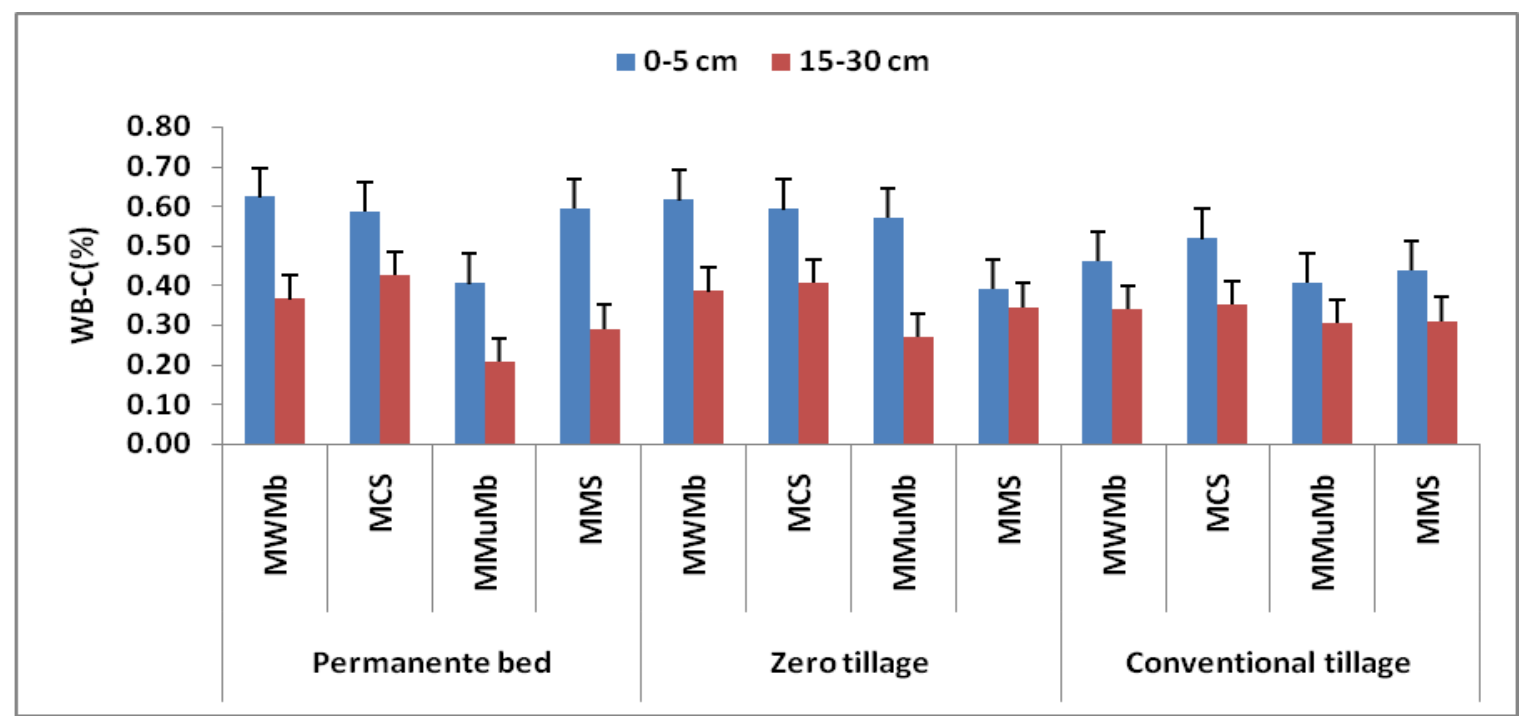

Adoption of CA significantly improved SOC status, and vis-à-vis soil biological activity. Relatively higher levels of WBC under longterm CA suggested greater possibility of $\mathrm{C}$ sequestration under PB and ZT over CT. Soil microbes flourished under $\mathrm{CA}$ practices resulting in higher DHA. Cropping systems like MWMb and MCS could be successfully adopted under CA to enhance SOC status which is the ultimate reservoir of plant nutrients and soil microbes and thus improvement of overall soil health can be achieved.

\section{Acknowledgement}

The first author would like to acknowledge Director, ICAR-IIMR for providing an opportunity to conduct present study in their on-going CA experiment. The financial assistance provided by the ICAR in the form of Junior Research Fellowship is also gratefully acknowledged.

\section{References}

Aulakh, M.S., Manchanda, J.S., Garg, A.K., Kumar, S., Dercon, G. and Nguyen,
M.L. 2012. Crop production and nutrient use efficiency of conservation agriculture for soybean-wheat rotation in the Indo-Gangetic Plains of Northwestern India. Soil and Tillage Research, 120, 50-60.

Bhattacharyya, R., Tuti, M.D., Kundu, S., Bisht, J.K., and Bhatt, J.C. 2012. Conservation tillage impacts on soil aggregation and carbon pools in a sandy clay loam soil of the Indian Himalayas. Soil Science Society of America Journal 76, 617-627.

Bouyoucos, G.J., 1962 Hydrometer method improved for making particle analysis of soil. Agronomy Journal 54, 464-465.

Casida, L.E., Klein, D.A. and Santoro, T. 1964. Soil dehydrogenase activity. Soil science 98, 371-376.

Chen, Z., Wang, H., Liu, X., Zhao, X., Lu, D., Zhou, J., and Li, C. 2017. Changes in soil microbial community and organic carbon fractions under short-term straw return in a rice-wheat cropping system.Soil and Tillage Research165, 121-127.

Dai, J., Hu, J., Zhu, A., and Lin, X. 2017. No- tillage with half- amount residue 
retention enhances microbial functional diversity, enzyme activity and glomalin- related soil protein content within soil aggregates. Soil Use and Management 33, 153-162.

Dey, A., Dwivedi BS, Bhattacharyya R, Datta SP, Meena MC, TK Das and Singh VK 2016. Conservation agriculture in a ricewheat cropping system on an alluvial soil of North-Western Indo-Gangetic Plains: Effect on soil carbon and nitrogen pools. Journal of the Indian Society of Soil Science 64, 246-254.

Gomez, K.A., and Gomez, A.A. 1984. Statistical Procedures for Agricultural Research. Second Edition. An International Rice Research Institute Book. A Wiley-Inter-science Publication, John Wiley and Sons, New York.

Halvorson, A.D., Wienhold, B.J. and Black, A.L. 2002. Tillage, nitrogen, and cropping system effects on soil carbon sequestration. Soil Science Society of America Journal 66, 906-912.

Hanway, J.J., and Heidel, H. 1952. Soil analysis methods as used in Iowa state college soil testing laboratory. Iowa Agriculture, 57, 1-31

He, Y.T., Zhang, W.J., Xu, M.G., Tong, X.G., Sun, F.X., Wang, J.Z., and He, X.H. 2015. Long-term combined chemical and manure fertilizations increase soil organic carbon and total nitrogen in aggregate fractions at three typical cropland soils in China. Science of the Total Environment 532, 635-644.

Jackson, M.L., 1973. Soil Chemical Analysis, Prentice Hall of India Pvt. Ltd., New Delhi.

Lal, R., 2015. A system approach to conservation agriculture. Journal of Soil and Water Conservation 70, 82A-88A

Lehman, R.M., Osborne, S.L., and Duke, S.E. 2017. Diversified no-till crop rotation reduces nitrous oxide emissions, increases soybean yields, and promotes soil carbon accrual. Soil Science Society of America Journal 81, 76-83.

Liu, C., Lu, M. Cui, J. Li, B. and Fang, C. 2014. Effects of straw carbon input on carbon dynamics in agricultural soils: a meta-analysis. Global

Biology 20, 1366-1381

Change

Mandal, N., Dwivedi BS, Meena MC, DhyanSingh, Datta SP, Tomar RK, Sharma BM 2013 Effect of induced defoliation in pigeonpea, farmyard manure and sulphitation press mud on soil organic carbon fractions, mineral nitrogen and crop yields in a pigeonpea-wheat cropping system. Field Crops Research 154, 178-187.

Meena, M.C., Dwivedi, B.S., Mahala, D. Das, S., and Dey A. 2017. Nutrient dynamics and management under conservation agriculture. In: System Based Conservation Agriculture. Westville Publishing House, New Delhi.

Nath, C.P., Das TK, Rana KS, Bhattacharyya R, Pathak H, Paul S, Meena MC and Singh SB 2017. Greenhouse gases emission, soil organic carbon and wheat yield as affected by tillage systems and nitrogen management practices. Archives of Agronomy and Soil Science 63, 1644-1660.

Olsen, B.C., Cole, C.V., Watenabe, F.S. and Dean, L.A. 1954. Estimation of available phosphorus by extraction with sodium carbonate. USDA, Circular No. 939, 19

Parihar, C.M., Yadav, M.R., Jat, S.L., Singh, A. K., Kumar, B., Pradhan, S. and Yadav, O.P. (2016) Long-term effect of conservation agriculture in maize rotations on total organic carbon, physical and biological properties of a sandy loam soil in north-western IndoGangetic Plains. Soil and Tillage Research 161, 116-128.

Punia, M., Nautiyal, V. P., and Kant, Y. 2008. 
Identifying biomass burned patches of agriculture residue using satellite remote sensing data. Current Science, 94, 9-10.

Singh, P., Heikkinen, J., Ketoja, E., Nuutinen, V., Palojärvi, A., Sheehy, J. and Regina, K. 2015. Tillage and crop residue management methods had minor effects on the stock and stabilization of top soil carbon in a 30-year field experiment. Science of the Total Environment 518, 337-344

Subbiah, B.V., and Asija, G.L. 1956. A rapid procedure for the estimation of available nitrogen in soils. Current Science 25, 518-522.

Thomas, G.A., Dalal, R.C. and Standley, J. 2007. No-till effects on organic matter, $\mathrm{pH}$, cation exchange capacity and nutrient distribution in a Luvisol in the semi-arid subtropics. Soil and Tillage
Research 94, 295-304.

Veihmeyer, F.J., and Hendrickson, A. 1948. Soil density and root penetration. Soil science 65, 487-494

Velayutham, M., Pal, D. K., and Bhattacharyya, T. 2000. Organic carbon stock in soils of India. Global Climate Change and Tropical Ecosystems, Pp. 71-95.

Walkley, A., and Black, I.A. 1934. An examination of Degtjareff method for determining soil organic matter and a proposed modification of the chromic acid titration method. Soil Science 37, 29-37.

Yang, X.M., and Wander, M.M. 1999. Tillage effects on soil organic carbon distribution and storage in a silt loam soil in Illinois. Soil and Tillage Research 52, 1-9.

\section{How to cite this article:}

Amresh Chaudhary, Mahesh C. Meena, Chiter M. Parihar and Abir Dey. 2017. Effect of LongTerm Conservation Agriculture on Soil Organic Carbon and Dehydrogenase Activity under Maize-Based Cropping Systems. Int.J.Curr.Microbiol.App.Sci. 6(10): 437-444.

doi: https://doi.org/10.20546/ijcmas.2017.610.053 